\title{
Analisa Faktor Kunjungan Wisatawan Mancanegara dan Penginapan Hotel Terhadap Penerimaan Sub Sektor PDRB pada Industri Pariwisata di Kabupaten Jember Tahun 2008-2018
}

\author{
Helmi Agus Salim \\ Sekolah Tinggi Ilmu Ekonomi Mandala \\ Email: helmi@stie-mandala.ac.id
}

https://doi.org/10.30741/wiga.v9i1.412

IN F O ART I K E L

Tanggal masuk :

1 Maret 2019

Tanggal Revisi :

20 Maret 2019

Tanggal Diterima :

31 Maret 2019
A B S T R A K

Indonesia merupakan salah satu negara dengan potensi sumber daya alam yang sangat besar yang bisa dimaksimalkan pada sektor industri wisata. Disamping itu besar harapan bahwa sektor wisata ini bisa meningkatkan PDRB di suatu daerah. Menurut hasil analisa, penelitian ini menunjukkan adanya pengaruh jumlah kunjungan wisatawan mancanegara dan hunian hotel terhadap penerimaan sektor PDRB industri pariwisata di Kabupaten Jember 2008-2018. Data yang digunakan adalah data deret waktu dari Biro Pusat Statistik dan Departemen Pariwisata. Penelitian ini menggunakan metode penelitian kuantitatif dan menggunakan model addjustmen parsial menggunakan proses time series. Dalam penelitian ini, variabel bebasnya adalah wisatawan mancanegara (W1) dan hotel (H2) sedangkan variabel terikatnya adalah PDRB (R). Hasil penelitian menggunakan analisis regresi berganda diketahui dan uji regresi simultan (Uji F) diketahui bahwa $\mathrm{F}$-stat 59,69 percaya diri di bawah 1 persen menunjukkan bahwa wisatawan asing dan hotel berpengaruh signifikan terhadap PDRB di Kabupaten Jember. Uji regresi parsial (uji t) menunjukkan adanya pengaruh yang signifikan antara variabel wisatawan mancanegara dan hunian hotel terhadap PDRB Kabupaten Jember. Besarnya pengaruh bahwa (R 2) dari 0,95. Artinya dari PDRB sebagai variabel dependen dijelaskan oleh variabel independen yaitu wisatawan mancanegara dan hunian hotel sebesar 95\% dan sisanya 5\% adalah dijelaskan oleh variabel - variabel lain di luar penelitian.

Kata Kunci : Wisatawan Asing, Hotel, PDRB Jember 
and hotel occupancy on the PDRP of Jember Regency. The magnitude of the effect is that (R2) of 0.95. This means that the PDRP as the dependent variable is explained by the independent variables namely foreign tourists and hotel occupancy by $95 \%$ and the remaining $5 \%$ is explained by other variables outside the research.

Keywords: Foreign Tourists, Hotels, PDRP Jember

\section{PENDAHULUAN}

Idonesia merupakan salah satu negara yang terkenal dengan keindahan alamnya. Flora dan fauna yang terdapat di sekitar 17.503 (5.707 sudah memiliki nama) pulau tersebar di zamrud katulistiwa memancarkan aura dan daya tarik yang sangat kuat bagi wisatawan baik lokal maupun manca negara. Sumber daya alam yang tersedia dari berbagai sektor (pertanian, pertambangan, perkebunan dan industri serta pariwisata) semakin memperkuat Indonesia menjadi salah satu tujuan favorit wisata di dunia. Pariwisata di Indonesia pada dasawarsa ini mulai menunjukkan perkembangan dan Pertumbuhan menjadi industri yang berdiri sendiri. Namun yang masih harus dipertimbangkan sampai saat ini tentang kesadaran dan pengertian dari pariwisata belum sampai ke masyarakat. Indonesia adalah negara yang memiliki keanekaragaman budaya dan memiliki nilai historis yang tinggi (Yuwana, 2010). Pariwisata itu sendiri industri jasa yang memiliki mekanisme pengaturan yang rumit karena mencakupperaturan untuk transfer wisatawan dari negara asal mereka, ke tujuan wisata, untuk kembali ke negara asal mereka yang melibatkan berbagai komponen seperti biro perjalanan, pemandu wisata, operator tur, akomodasi, restoran, toko, penukaran uang, transportasi dan banyak lagi.

Indonesia adalah negara yang memiliki keanekaragaman budaya dan memiliki nilai historis yang tinggi (Yuwana, 2010). Pariwisata itu sendiri merupakan industri jasa yang memiliki mekanisme pengaturan yang rumit karena mencakup pengelolaan untuk transfer wisatawan dari negara asal mereka, ke tujuan wisata, untuk kembali ke negara asal mereka yang melibatkan berbagai komponen seperti biro perjalanan, pemandu wisata, operator tour, akomodasi, restoran, artshop, penukaran uang, transportasi dan banyak lagi. Pariwisata juga menawarkan berbagai produk dan wisata, mulai dari wisata alam, wisata budaya, wisata sejarah, wisata buatan, hingga berbagai wisata minat khusus (Hutasoit, 2017). Menurut Salah Wahab dalam bukunya "Manajemen Pariwisata" pariwisata adalah salah satu jenis industri baru yang mampu menunjukkan pertumbuhan ekonomi yang cepat dalam penyediaan lapangan kerja, standar hidup, dan mampu merangsang sektor produktivitas lainnya.Selain sebagai sektor yang kompleks, sektor ini juga mencakup industri klasik nyata seperti industri kerajinan dan souvenir.

Kabupaten Jember adalah salah satu kabupaten di Jawa Timur yang memiliki sektor pariwisata strategis dan memiliki potensi untuk dikelola dan dipasarkan selain sebagai daerah pertanian dan perdagangan yang mampu menyerap banyak tenaga kerja dan memberikan kontribusi besar terhadap PDRB. Keberhasilan pengembangan sektor pariwisata mampu berperan dalam meningkatkan pendapatan daerah di sektor PDRB Kabupaten Jember. Terdapat beberapa potensi yang dikembangkan, baik itu wisata alam, wisata budaya maupun wisata religi yang tersebar di beberapa daerah dan beberapa objek wisatanya ada yang terkenal hingga ke mancanegara. Banyak wisatawan manca negara berkunjung ke Jember baik dari negara tetangga seperti Malasyia, Singapura, Thailand dan lain sebagainya maupun wisatawan dari Amerika Serikat Eropa Australia Uni Emirat Arab dan lain sebagainya. Kedatangan wisatawan mancanegara ke Jember bisa dari tiga pintu masuk kabupaten lain. Dari sebelah barat pintu masuk dari kabupaten lumajang.Dari pintu utara dari Kabupaten Bondowoso, dan dari pintu sebelah timur dari Kabupaten Banyuwangi.Berikut adalah tabel jumlah pengunjungwisatawan mancanegara diKabupaten Jember tahun 2005-2018:

Tabel 1. Data Jumlah PengunjungWisatawan Mancanegara di Kabupaten Jember 


\begin{tabular}{ccccc}
\hline No & Tahun & $\begin{array}{c}\text { Jumlah } \\
\text { Wisatawan } \\
\text { Manca } \\
\text { Negara }\end{array}$ & $\begin{array}{c}\text { Jumlah } \\
\text { Hunian }\end{array}$ & PDRB (juta) \\
\hline 1 & 2005 & 707 & 326 & $127.181,71$ \\
2 & 2006 & 269 & 261 & $139.757,40$ \\
3 & 2007 & 286 & 475 & $160.618,56$ \\
4 & 2008 & 417 & 1.190 & $197.015,40$ \\
5 & 2009 & 559 & 40 & $139.992,33$ \\
6 & 2010 & 628 & 96 & $161.371,26$ \\
7 & 2011 & 1.012 & 44 & $189.003,90$ \\
8 & 2012 & 1.682 & 53 & $218.972,07$ \\
9 & 2013 & 1.869 & 58 & $256.586,45$ \\
10 & 2014 & 2.672 & 332 & $279.993,10$ \\
11 & 2015 & 3.017 & 345 & $308.133,40$ \\
12 & 2016 & 2.751 & 220 & $356.483,00$ \\
13 & 2017 & 3.178 & 375 & $403.375,70$ \\
14 & 2018 & 3.058 & 408 & $462.461,80$ \\
\hline
\end{tabular}

Sumber: BPS dan Dinas Pariwisata

Dari tabel diatas dapat kita amati bahwa ada peningkatan kunjungan wisatawan mancanegara ke Kabupaten Jember setiap tahunnya. Peningkatan kedatangan wisatawan mungkin disebabkan oleh faktor alam yang baik, situs wisata yang memadai, tempat wisata yang indah, dan juga didorong karena keberadaan fasilitas wisata yang lengkap. Tahun 2005 jumlah wisatawan orang asing yang datang ke Kabupaten Jember adalah 707 orang pada tahun 2018, turis asing mengunjungi yang mengunjungi kabupaten Jember sebanyak 3,058 orang. Itu berarti semakin banyak turis asing setiap tahun akan memiliki dampak positif pada PDRB serta pengembangan dan pengembangan pariwisata di kabupaten Jember. Peningkatan jumlah kunjungan wisatawan asing sangat berpengaruh pada tingkat hunian hotel. Wisatawan asing sedang mencari tempat tinggal sementara ketika mereka bepergian atau berlibur Kabupaten Jember. Industri perhotelan adalah kategori luas dalam bidang industri jasa yang meliputi penginapan, restoran, perencanaan acara, taman hiburan, transportasi, jalur pelayaran, dan bidang tambahan dalam industri pariwisata.

Hotel adalah tempat yang disediakan bagi wisatawan untuk menginap selama mereka berkunjung atau tempat dalam melakukan kegiatan wisata. Selain itu, sebelum melakukan kegiatan pariwisata, seorang turis memerlukan informasi tentang informasi daerah yang akan dituju beserta fasilitasfasilitasnya. Hotel adalah fasilitas akomodasi utama yang ingin diketahui wisatawan sebelum bepergian. Karena itu, keberadaan hotel ini mutlak dibutuhkan. Jumlah wisatawan asing meningkat setiap tahun, sehingga harus diimbangi dengan penyediaan layanan akomodasi untuk wisatawan asing. Kemajuan industri di bidang perhotelan dapat diketahui perkembangannya melalui beberapa indikator seperti jumlah hotel/ akomodasi, tingkat hunian kamar, jumlah kamar yang dijual dan rata-rata lamanya menginap (Hutasoit, 2017).

Jumlah hunian hotel untuk turis manca negara mengalam fluktuasi dari tahun ketahun.Tahun 2005 tercatat sebanyak 326 kamar. Tahun 2008 meningkat tajam menjadi 1.190 kemudian pada tahun 2018 turun lagi menjadi 408 kamar. Kedua faktor yang berhubungan dengan jumlah wisatawan mancanegara dan jumlah hunian hotel diyakini oleh pemerintah sangat berpengaruh terhadap penerimaan sub sektor PDRB industri pariwisata di Kabupaten Jember. Penelitian ini bertujuan untuk melihat kedua faktor ini, apakah ia memiliki pengaruh yang sangat besar terhadap PDRB terutama di sektor industry pariwisata selain di Kabupaten Jember. Rumusan masalah dalam penelitian ini adalah : a. Bagaimana pengaruh jumlah kunjungan wisatawan mancanegara terhadap penerimaan sub sektor PDRB industri pariwisata di Kabupaten Jember? b. Bagaimana pengaruh jumlah hunian hotel terhadap penerimaan sub sektor PDRB industri pariwisata di Kabupaten 
Jember?. Berdasarkan rumusan masalah diatas, selanjutnya dapat ditulis tujuan penelitiannya adalah sebagai berikut: a. Untuk mengetahui seberapa besar pengaruh jumlah kunjungan wisatawan asing terhadap penerimaan sektor PDRB industri pariwisata di Kabupaten Jember. b. Untuk mengetahui seberapa besar pengaruh hunian hotel terhadap pendapatan sektor PDRB industri pariwisata di Kabupaten Jember.

\section{METODE PENELITIAN}

Penelitian ini dilakukan di Kabupaten Jember yang merupakan salah satu kabupaten di Jawa Timur yang memiliki tujuan wisata dengan sumber daya alam dan budaya yang menarik untuk dikembangkan sebagai kawasan wisata dan merupakan lahan potensial bagi investor untuk berinvestasi di sektor ini. Definisi operasional menggambarkan metode khusus yang digunakan oleh peneliti internal dalam mengukur variabel yang akan digunakan.Terdapat dua variabel bebas dan satu variabel terikat yang digunakan dalam analisis pengaruh terhadap industri pariwisata di Kabupaten Jember.

Variabel - variabel dalam penelitian ini secara operasional dapat didefinisikan sebagai (1) Penerimaan Sektor PDRB yang Merupakan besarnya penerimaan sektor PDRB pada industri pariwisata di Kabupaten Jember tahun 2005 - 2018. Data jumlah penerimaan sektor PDRB dihitung dengan harga berlaku (2) jumlah wisatawan asing adalah jumlah wisatawan asing yang berkunjung ke Kabupaten Jember. Data jumlah kunjungan wisatawan asing dihitung dalam satuan orang (3) jumlah hunian hotel merupakan banyaknya penginapan yang digunakan oleh wisatawan asing ketika melakukan liburan / perjalanan di Kabupaten Jember. Data hunian hotel diukur dalam satuan unit.

Jenis data yang digunakan dalam penelitian ini adalah data sekunder. Data sekunder merupakan data yang diperoleh dari pihak lain, baik dari literatur, studi pustaka, atau penelitian-penelitian sejenis sebelumnya yang berkaitan dalam penelitian ini. Data sekunder yang digunakan dalam penelitian ini diperoleh dari Badan Pusat Statistik (BPS) Kabupaten Jember, Dinas Pariwisata Kabupaten Jember, dan literatur-literatur lainnya seperti buku-buku, dan jurnal-jurnal ekonomi.Data yang tersedia adalah data tahunan.Periode peneiltian dimulai tahun 2005 sampai dengan 2018.

Alat analisis yang digunakan dalam penelitian adalah analisi regresi linear berganda dihitung dengan menggunakan alat analisisis time series pocessor. Model dasar dalam penelitian ini dapat ditulis sebagai berikut:

$\mathrm{R}=\mathrm{b}_{\mathbf{0}}+\mathrm{b}_{1} \mathrm{~W}_{1}+\mathrm{b}_{2} \mathrm{H}_{2}+\mathrm{e}$

Keterangan penanda:

$\mathrm{R}=$ Penerimaan PDRB Sektor Industri Perhotelan (rupiah)

W= Jumlah Kunjungan Wisatawan Mancanegara (orang )

$\mathrm{H}=$ Jumlah Hunian Hotel (angka)

Untuk mendapatkan model persamaan regresi yang baik dan benar-benar mampu memberikan estimasi yang handal dan tidak bias sesuai kaedah BLUE (best, linier, and unbiase estimator), maka diperlukan uji terhadap penyimpangan asumsi klasik meliputi: uji normalitas digunakan untuk mengetahui apakah populasi data berdistribusi normal atau tidak, uji multikolinieritas berfungsi untuk menguji apakah pada model regresi ditemukan adanya suatu hubungan linier yang sempurna (mendekati sempurna) antara beberapa atau semua variabel bebasnya, uji heterokedastisitas untuk menguji apakah dalam model regresi terjadi ketidaksamaan varian dari residual suatu pengamatan ke pengamatan lain dan uji autokorelasi untuk mengetahui adanya korelasi antar anggota serangkaian observasi yang diurutkan menurut waktu (seperti dalam data runtut waktu atau time series). 
Alat analisis yang digunakan dalam penelitian adalah analisis regresi linear berganda, dengan model penyesuaian parsial (partial adjustment model) sebagai salah satu model dinamis dalam analisis regresi. Persamaan model penyesuaian parsial diturunkan dari model pada persamaan diatas ditulis sebagai berikut:

$\mathrm{LR}=\mathrm{b}_{\mathbf{0}}+\mathrm{b}_{1} \mathrm{LW}_{1}+\mathrm{b}_{2} \mathrm{LH}_{2}+\mathrm{b}_{3} \mathrm{LR}(-1)+\mathrm{e}$

Keterangan penanda:

LR = Penerimaan PDRB Sektor Industri Perhotelan (rupiah)

$\mathrm{LW}_{1}=$ Jumlah Kunjungan Wisatawan Mancanegara (orang )

$\mathrm{LH}_{2}=$ Jumlah Hunian Hotel (angka)

LR $(-1)=$ Variabel Kelambanan LR

$\mathrm{b}_{0}=$ Intersep $/$ Konstanta

$\mathrm{b}_{1}=$ Koefisien Regresi Jumlah Kunjungan Wisatawan Mancanegara

$\mathrm{b}_{2}=$ Koefisien Regresi Jumlah Hunian Hotel

$\mathrm{b}_{3}=$ Koefisien Kelambanan LR

$\mathrm{e}=$ Disturbance Error ( Variabel Penganggu )

$\mathrm{L}=$ Nilai $\log$ data penelitian

Dari bentuk fungsi regresi model penyesuaian parsial diatas kemudiandibuat analisis regresi jangka panjang sebagai berikut:

$\mathrm{LR}=\mathrm{c}_{\mathbf{0}}+\mathrm{c}_{1} \mathrm{LW}_{1}+\mathrm{c}_{2} \mathrm{LH}_{2}$

Dimana:

$\mathrm{c}_{0}=\mathrm{b}_{0} /\left(1-\mathrm{b}_{3}\right) ;$ intercept

$\mathrm{c}_{1}=\mathrm{b}_{1} /\left(1-\mathrm{b}_{3}\right)$; koefisien jangka panjang wisman (orang)

$\mathrm{c}_{2}=\mathrm{b}_{2} /\left(1-\mathrm{b}_{3}\right)$; koefisien jangka panjang hunian hotel (kamar)

LR $=$ Log PDRB subsektor pariwisata (Rupiah)

Uji ini dilakukan untuk menunjukkan apakah semua variabel bebas yang dimasukkan dalam model mempunyai pengaruh secara bersama-sama terhadap variabel terikat (Ghozali, 2013).

$\mathrm{H}_{0}=\mathrm{b}_{1}=\mathrm{b}_{2}=0$

$\mathrm{H}_{\mathrm{a}}=\mathrm{b}_{1}=\mathrm{b}_{2}=0$

Dengan kriteria bahwa $\mathrm{H}_{0}$ diterima jika F-hitung < F-tabel maka $\mathrm{H}_{0}$ diterima. Artinya variabel independen secara keseluruhan tidak berpengaruh signifikan terhadap variabel dependen. Sedangkan $\mathrm{H}_{0}$ ditolak jika F-hitung $>$ F-tabelmaka $\mathrm{H}_{0}$ ditolak. Artinya variabel independen secara keseluruhan berpengaruh signifikan terhadap variabel dependen.

Digunakan untuk mengetahui apakah hipotesis masing-masing variabel bebas berpengaruh terhadap variabel tidak bebas, dengan level pengujian 5\%. Uji t dapat dilakukan dengan kriteria berikut :

$\mathrm{H}_{0}=\mathrm{b}_{1}=0$

$\mathrm{Hi}=\mathrm{b}_{1} \neq 0$

Hipotesis dalam uji t menunjukkan jika t-hitung < t-tabelmaka $\mathrm{H}_{0}$ diterima dan $\mathrm{H}_{1}$ ditolak, berarti bahwa secara individual variabel independen tidak berpengaruh terhadap variabel dependen. Sedangkan jika t-hitung >t-tabel makaH$_{0}$ ditolak dan $\mathrm{H}_{1}$ diterima, berarti bahwa secara individual variabel independen berpengaruh terhadap variabel dependen.

Menurut Ghozali (2013) koefisien korelasi (R) digunakan untuk menganalisis atau mengetahui hubungan anatara variabel independen dan variabel dependen, sehingga dapat ditentukan nilai korelasi murni yang terlepas dari pengaruh-pengaruh variabel lainnya.

Uji koefisien determinasi (R2) yaitu pengujian dari dari semua variabel independen bersama-sama pada variabel dependen, jika R2 lebih dekat ke 1, adalah indikator yang menunjukkan pengaruh variabel X kuat pada variabel dependen (Ghozali, 2013). Untuk mengetahui apakah variabel Xi 
dan variabel $\mathrm{Y}$ memiliki hubungan, analisis korelasi $\mathrm{R}=1$ digunakan, artinya hubungan antara variabel $\mathrm{X}$ dan $\mathrm{Y}$ adalah sempurna dan positif. Jika mendekati 1, variabel X dan Y, Y sangat kuat dan positif. Sedangkan $\mathrm{R}=-1$, artinya hubungan antara variabel $\mathrm{X}$ dan $\mathrm{Y}$ adalah sempurna dan negatif. Jika mendekati 1 , variabel $\mathrm{X}$ dan $\mathrm{Y}$, Y sangat kuat dan positif. Dan jika $\mathrm{R}=0$, itu berarti tidak ada hubungan antara variabel $\mathrm{X}$ dan variabel $\mathrm{Y}$. Ketika mendekati 0, hubungan antara variabel $\mathrm{X}$ dan variabel $\mathrm{Y}$ sangat lemah.

\section{HASIL DAN PEMBAHASAN}

Berdasarkan hasil pengolahan data menggunakan program time series processor, hasil perhitungan regresi dengan model penyesuaian parsial (pam) dapat dilihat pada table berikut:

Tabel 2. Hasil Analisis Regresi

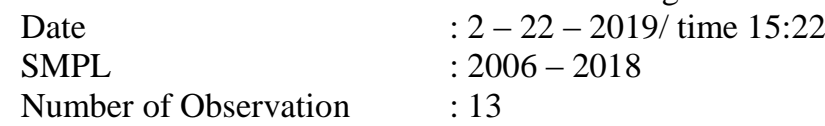

\begin{tabular}{llllll}
\hline Variables & Coefficient & STD Error & T-Stat & 2-Tail Sig \\
\hline C & 12.960566 & 4.6139288 & 2.8090088 & 0.0204 & \\
LW & 0.2326440 & 0.0778778 & 2.9872947 & 0.0153 & \\
LH & 0.0973929 & 0.0314737 & 2.9872947 & 0.0128 & \\
LR (-1) & 0.4242618 & 0.1992121 & 2.1296990 & 0.0621 & \\
& & & & \\
R $^{2}$ & & $=0.952148$ & Mean of Dep Var & $=26.17586$ \\
Adj R & & $=0.936197$ & S.D of Dep Var & $=0.402393$ \\
S.E of Reg & $=0.101642$ & Sum of S. Resid & $=0.092979$ \\
Log Likelihood & $=13.66593$ & F-Statistic & $=59.69266$ \\
Durbin Watson Stat & $=1.95$ & Prob (F-Stat) & $=0.000003$ \\
\hline
\end{tabular}

Berdasarkan tabel 2 diatas diperoleh persamaan regresi jangka pendeksebagai berikut: $\mathrm{LR} \quad=12,960+0.233 \mathrm{LW}+0.097 \mathrm{LH}+0.424 \mathrm{LR}(-1)$

Dengan menganggap bahwa hasil estimasi model penyesuaian parsial di atas dihasilkan transformasi Koyek, maka dapat dikemukakan bahwa besarnya nilai tingkat penurunan (rate of decline $), \mathrm{b}_{3}=0.4242$ atau mean lag $\left(\mathrm{b}_{3} /\left(1-\mathrm{b}_{3}\right)=0.4242 /(1-0.4242)=0.7367\right.$. Ini berarti bahwa sekitar 42.42 persen dari gap akan tertutup dalam satu periode dengan kecepatan LR dalam merespon perubahan variabel bebas adalah sekitar 2.21 tahun. Dari hasil regresi ditas selanjutnya dapat dihitung persamaan jangka panjang sebagai berikut:
K $\quad: 12.960 /(1-0.424)=22.510$
LW $: 0.233 /(1-0.424)=0.399$
LH $\quad: 0.097 /(1-0.424)=0.168$
$\mathrm{LR} \quad=22.510+0.39 \mathrm{LW}+0.168 \mathrm{LH}$

\section{PEMBAHASAN}

Dari hasil analisis regresi dapat diketahui bahwa jumlah kunjungan wisatawan mancanegara berpengaruh signifikan statistik terhadap PDRB Sektor Industri Pariwisata. Hal ini dapat dilihat dari koefisien regresi sebesar 0.339. Secara teori ekonomi dapat dikatakan bahwa jika kunjungan wisatawan mancanegara naik sebesar persen maka akan mengakibatkan kenaikan jumlah penerimaan PDRB sektor industri pariwisata Kabupaten Jember sebesar 0.339 persen. Koefisien variabel signifikan positif secara statistik dapat dilihat dari angka 2 tail signifikansi dengan derajat kepercayaan kurang dari 1 persen. 
Jumlah wisatawan asing adalah jumlah wisatawan yang berkunjung ke suatu negara setiap tahun didorong oleh satu atau beberapa kebutuhan tanpa bermaksud mendapatkan pekerjaan dan penghasilan di tempat yang dikunjungi dalam periode yang ditentukan yang diukur pada unit orang. Jumlah kunjungan wisatawan asing ke Kabupaten Jember cenderung meningkat, meskipun tingkat pertumbuhannya bervariasi tergantung pada situasi ekonomi, sosial, teknologi dan politik yang terjadi di dalam negari dan luar negeri. Dalam perkembangan pariwisata sebagai industri, jumlah penduduk suatu negara selalu menjadi perhatian, selain Produk Nasional Bruto (PDB) negara yang bersangkutan. Secara teoritis hanya penduduk berpenghasilan tinggi yang bisa kemungkinan melakukan perjalanan wisata

Dari hasil analisis regresi dapat diketahui bahwa jumlah hunian hotel berpengaruh signifikan statistik terhadap PDRB Sektor Industri Pariwisata.Hal ini dapat dilihat dari koefisien regresi sebesar 0.168. Secara ekonomi dapat dikatakan bahwa jika jumlah hunianhotel naik sebesar 1 persen maka akan mengakibatkan kenaikan jumlah penerimaan PDRB sektor industri pariwisata Kabupaten Jember sebesar 0.168 persen. Koefisien variabel signifikan positif secara statistik dapat dilihat dari angka 2 tail signifikansi dengan tingkat kepercayaan kurang dari 1 persen.

Hotel adalah tempat tinggal sementara / penginapan yang digunakan saat bepergian atau berlibur di daerah tujuan wisata. Perkembangan hotel ini sangat berpengaruh terhadap penerimaan sektor PDRB. Hotel dan wisatawan asing sangat dekat hubungannya, di mana ketika wisatawan berlibur ke tujuan wisata akan mencari hotel untuk tinggal sementara. Dengan memperhatikan dan meningkatkan layanan hotel, akan menjadi daya tarik bagi wisatawan. Di mana wisatawan juga ingin memiliki tempat istirahat yang nyaman dengan fasilitas dan infrastruktur yang baik. Pengembangan perhotelan di dalam industri pariwisata sangat diperlukan, karena akan meningkatkan pendapatan daerah / negara. Semakin banyak wisatawan asing yang ingin berlibur maka semakin tinggi pemakaian hotel setiap tahunnya. Karena wisatawan akan menemukan tempat untuk beristirahat selama liburan mereka tujuan wisata (DTW). Semakin tinggi permintaan dari wisatawan asing terhadap Penggunaan hotel setiap tahun, pengaruhnya akan semakin tinggi menuju PDRB regional.

\section{KESIMPULAN}

Berdasarkan hasil penelitian mengenai pengaruh jumlah wisatawan manca negara dan jumlah kunjungan hotel terhadap realisasi PDRB sektor industri pariwisata, ditemukan pengaruh yang signifikan artinya jika variabel wisatawan mancanegara dan hotel meningkat maka PDRB industri pariwisata juga meningkat. Berdasarkan koefisien determinasi berganda $\left(R^{2}\right)$ sebesar 0,9521 bahwa variabel wisatawan mancanegara dan hotel memiliki 95,21\% pengaruh terhadap PDRB industri pariwisata di Kabupaten Jember. Sedangkan sisanya 4,79\% dipengaruhi oleh variabel lainnya yang tidak dibahas dalam penelitian tersebut. Hal ini juga ditunjang dengan hipotesis yang berpengaruh positif dari data yang diambil dari tahun 2005 - 2018. Dari hasil tersebut penulis menyarankan kepada pemerintah kabupaten Jember melalui Dinas Pariwisata Kabupaten Jember untuk meningkatkan promosi pariwisata di luar negeri dan mengeksplor obyek daya tarik wisata (ODTW) yang baru untuk menarik wisatawan mancanegara lebih lama tinggal di Kabupaten Jember serta mendorong aktivitas perekonomian yang dapat meningkatkan pertumbuhan ekonomi yang lebih tinggi dari periode-periode sebelumnya yang dapat memperluas kesempatan berusaha dan bekerja, sehingga akan meningkatkan PDRB di suatu daerah.

\section{DAFTAR PUSTAKA}

Dinas Pariwisata Kabupaten Jember, 2005 - 2018. Data Jumlah Kunjungan Wisatawan Mancanegara 2005-2018.Jember

Biro Pusat Statistik, berbagai terbitan, Jember

Ghozali, I. (2013) Aplikasi Analisis Multivariate dengan Program IBM SPSS 21 Update Pls Regresi. Semarang. Penerbit Universitas Diponegoro 
Sunaryo, B. (2013). Kebijakan Pembangunan Destinasi Pariwisata. Gava Media. Yogyakarta.

Tanjung, D. N. (2011). Faktor-Faktor Yang Mempengaruhi Berkembangnya Potensi Pariwisata di Kabupaten Pelelawan Provinsi Riau. Fakultas Ekonomi, Universitas Riau.

Undang-Undang Republik Indonesia Nomor 10 Tahun 2009.2009. Tentang Pengertian Pariwisatadan Peraturan yang Berlaku.Dewan Perwakilan Rakyat Republik Indonesia.

Hutasoit, N. (2017), Pengaruh Jumlah Kunjungan Wisatawan Mancanegara dan Jumlah Hunian Hotel terhadap Penerimaan Sub Sektor PDRB Industri Pariwisata di Propinsi Sumatera Utara Tahun 2004 - 2013, JOM, Fekon, Univ Riau, Pekan Baru

Yoeti, O. A. (2008). Ekonomi Pariwisata. Jakarta: Kompas.

Yudananto, W. (2011). Peranan Sektor Pariwisata Terhadap Perekonomian Daerah di Indonesia (Analisis Interregional Input-Output). ASSETS : Jurnal Universitas Padjajaran Bandung.h:1-12. 